\title{
Why Leadership? Why Now?
}

\section{Helen M. Gunter}

The University of Manchester - Manchester Institute of Education (UK)

doi: 10.7358/ecps-2015-011-gunt

helen.gunter@manchester.ac.uk

\section{PERCHÉ LA LEADERSHIP? PERCHÉ ORA?}

\section{Abstract}

The rapid growth of leaders, doing leadership and exercising leadership in Anglophone countries has generated a context in which those outside may wish to investigate with a view to borrowing and developing their own agenda. In this paper I examine the experiments in England by successive UK governments, where I draw on research evidence from a range of projects to both describe and critically examine the agenda. I raise serious questions for policymakers, professionals and researchers who are located within and interested in "Educational leadership in Latin Europe", notably that the purposes, rationales and narratives within England are less about educational leadership and more about functional delivery and outcome measures. I show how this is linked to the wider privatization that is unfolding in England, and I raise evidence about how alternative approaches are in evidence within practice and research. Consequently there is a range of resources that those in Latin Europe might draw on and use to support thinking and strategizing.

Keywords: Educational leadership, Education policy, Leadership, Leadership reform in England, Reform of education.

\section{INTRODUCTION}

At the Educational leadership in Latin Europe Conference in Rome in December 2013 I spoke about England as a site of major financial and symbolic investment in school leadership with rapid changes to roles, work and status. The talk was based on a range of research that has taken place in the past twenty years with data sets of interviews with over 300 people (teach- 
ers, children, headteachers, unions, local authorities, ministers, civil servants, researchers and private consultants), and over 300 primary and 500 secondary sources (see Gunter, 2012, 2014 and 2015). A key outcome from this work is that the current prominence of leaders, doing leading and exercising leadership is not of itself new, but what is different is the way that governments around the world have used this localised and organisational power process as the means through which to secure radical reforms. Importantly those reforms are focused on education, but did not directly develop educational leadership, and while those reforms were undertaken by the UK government in England they were influenced by, and actively influenced, the global travelling of knowledge claims and production processes about transformational and effective leadership. The relationship between the growth of leadership and the reform context is significant: the advance of a particular form of leader, leading and leadership in England is a product of a privatisation agenda, and it shapes that agenda as well. The purposes of leaders, doing leading and exercising leadership, together with the rationales for doing this and the narratives that explicate it are driven by the generation of new educational products within an increasingly competitive market, and as leaders use leading and leadership to operate within this market they enhance and legitimise such forms of professional practice in ways that are normal and normalising. In this paper I intend developing these ideas with a view to providing a resource for those interested in examining both educational leadership and how it is located within Latin Europe. Importantly I begin by examining how and why leadership has been invested in, and I then go on to examine what this means in regard to how this is read, used, and acted upon.

\section{ENGLAND AS A LEADERSHIP LABORATORY}

A former UK government Secretary of State for Education once said to me that: «[...] we always knew we couldn't do what we wanted in education unless we turned round leadership» (Gunter, 2012, p. 19). This simple yet powerful statement about the efficacy and necessity of improving the leadership of schools in England is illuminative of the investment in leadership as a means of bringing about major reforms. The statement is about education policy processes within the first New Labour government from 1997, but in many ways it is timeless in the contemporary history of the reform of education as it could have been spoken from the 1970s onwards and continues to be evident in ministerial discourses today. From the 1970s onwards concerns about quality in public education came to dominate discourse and election 
campaigns, where successive governments focused on the purposes and outcomes of public investment, not least in relation to the global economy. Such claims also have international resonance whereby the OECD has not only made links between leadership and good governance, but also put emphasis on the identification, selection and training of future leaders for public services (OECD, 2001). Education is a particular focus, where the OECD has identified the importance of leaders for improvement, the challenges of securing this, and what are identified as the «levers» that can be used to build capacity and capabilities (Pont et al., 2008). The significance of this is also found in the cross-national studies of leaders, doing leading and exercising leadership, whereby researchers continue to map and examine within national and cross nation similarities and differences (e.g. National College for Leadership of Schools and Children's Services, 2010).

By identifying England as a laboratory I am raising the issue that policymakers have experimented with leadership in ways that other countries looked upon and investigated in regard to what they could learn and possibly borrow. With this in mind I intend examining what might be learned, and through research might be learned differently, about the experience of England, and how this experience might be read by those interested in thinking about educational leadership in Latin Europe.

Much policy borrowing has gone on in regard to the reforms in England, whereby there has been overt taking of ideas and strategies (e.g. national standards for school leaders) as well as the building of confidence and affirmation that while particular reforms in different countries might have differences, the underlying purposes and direction of travel are the same (e.g. the introduction of private investment, ownership, and profit). Here I summarise the key changes that have taken place in England:

- Educational provision: schools independent of local governance structures have been set up. Some based on exiting of the local system such as Grant Maintained Status from 1988, some based on new forms of provision outside of local provision such as City Technology Colleges from the mid 1980s, and Free Schools from 2010, and some hybrids were Academies from 2000 include conversions of existing schools and the creation of new schools.

- School workforce: the workforce has been widened to include more nonteachers who undertake site-based management, for example, School Business Managers, and those in senior roles have been separated from the main workforce through pay and background (the person in charge may not be a teacher but a Chief Executive).

- Professional work and identities: the preferred model of Transformational Leadership has been adopted and promoted through national standards 
training and accreditation for aspiring and serving leaders through the National College for School Leadership from 2000 (and renamed and remodeled: National College for Teaching and Leadership from 2013). The headteacher (or principal) is positioned as the originator and causal link for improved student outcomes, and this is controlled through performance management regimes (e.g. performance related pay) in order to measure and reward the local delivery of national reforms.

These changes are integral to a privatization agenda, whereby the independent school separate from local democratic control is presented as the role model for effectiveness within a competitive market place. Schools as businesses are therefore required to have charismatic leaders who are able to identify and secure income streams and to market the school as a product to parents and children who exercise choice. Such leaders may come from the ranks of trained teachers, but could also be infused with new dispositions and skills through career paths outside of education and public services. This agenda is linked ideologically to neoliberal claims about the inefficiencies of public bureaucracy and the need to open up provision to private interests and providers, and to neoconservative claims about the damage done to parents and families through educational professionals teaching and communicating knowledge and values that are contrary to their private belief systems. The agenda may not be coherent or pursued in logical ways through debates and policies, but is very powerful through its capture of political parties of the right and left, and through the media. An important outcome is that significant changes have been made to leaders, leading and leadership: first, headteachers have faced major interventions into their roles, work and identities, not least in regard to their positioning as localized reform deliverers, where acclaim and attack operate through performance data and competitive positioning in league tables; second, other school personnel have been upgraded through the adoption of «leader» «leading» and «leadership» to augment their professional titles (e.g. teacher leadership) and the promotion of functional distributed leadership as a form of performance delegation; third, local authority personnel have faced downsizing and redundancy with either retirement or relocation into consultancy businesses; and fourth, new actors have developed a strong voice about leaders, leading and leadership through their sponsorship of new forms of schooling and by philanthropic investments (see Ball, 2007; Butt \& Gunter, 2007; Gunter, 2011).

A serious consequence of this is that leaders, leading and leadership has been less about education and more about other matters. Let me say some more.

Educational leadership is concerned directly with pedagogic processes. Leadership is therefore not just about teaching and learning, but is within 
and for it, where participants are educated through exercising leadership as an educative process. In this sense leadership as an exercise of power is, in Foster's (1986) terms, a shared and communal concept, whereby through relational encounters in classrooms, corridors, offices and meeting rooms ideas and actions are engaged with and exchanges take place. What is crucial about the experiments conducted in England is that the approach to leadership is not primarily educational leadership. While the headmaster tradition has put emphasis on the single person as «teacher» leading a community of staff and children, this has been reworked through neoliberal and neoconservative ideologies and strategizing into organizational and systemic conceptualisations (Grace, 1995). What is evident is an emphasis from the 1980s onwards on the school as an effective and efficient organization, with the headteacher as the charismatic entrepreneurial leader, as a form of school leadership. Site based management from the 1980s generated a market imperative for the headteacher to perform in order to recruit students, staff and investment. So school leadership is about organizational efficiency, effectiveness and excellence, where attention is given to the conditions in which teaching and learning takes place, and the outcomes from this through an examination of test and other data (e.g. attendance and punctuality statistics). An emphasis was put on strategic planning, the management of change, human resources management, and marketing. Centralisation of the curriculum (from 1988) and standards (from 1992 with Ofsted) inter-related national command and control with localized enactment. This generated a leadership of schools system whereby national government (or their agents, e.g. the National College, or their supporters e.g. rich philanthropists) bypassed or dismantled local authorities with direct interventions into the curriculum, teaching, learning and assessment, and through the direct funding of new types of schools (e.g. Academies, Free Schools). The post of headteacher was remodeled with the opportunities given to non-teachers to head up educational provision as "principals», and new systemic responsibilities where developed through executive roles in running more than one school, or heading up new federations of groups of schools, or leaving the local system to work within private chains of academies, and more recently free schools. So the current purposes of leaders, leading and leadership are about strategic positioning in a competitive market place, where new actors such as philanthropists or established power structures such as faith groups are the controllers and "owners» of schools. The rationales are about delivering education in ways that meet national standards and market choices, with narratives about learning outcomes and effective teaching. 


\section{THINKING ABOUT EDUCATIONAL LEADERSHIP}

What this account about leaders, leading and leadership in England does is to generate questions about how and why this has happened. There is a complex inter-weaving of national, sub-national and supra-national institutions where policy is made, and particular types of knowledge, ways of knowing and trusted knowers are involved (see Gunter, 2012). Governments take office through elections, with a mandate to govern, where events and realpolitik may challenge reform programmes. A key feature is that public policy draws on knowledge that can be based on ideologies, beliefs, and research evidence. Governments may commission and use evidence, or they may not, or both.

My work on the situation in England shows that knowledge exchanges with particular knowers who use particular forms of knowledge take place within public institutions. I call this institutionalized governance, whereby ministers and civil servants call in people to advise them, lead on projects, or even take up employment as reform delivers.

This forms what I call a government regime of practice, whereby headteachers are called in to give their views, or to take up roles in the National College; professors and researchers give evidence informed advice, and may lead on commissioned projects; private sector consultants are called in to give advice, to present solutions, and may lead on commissioned projects. Government is seeking legitimacy of the profession, the academy and business, and this is best illustrated through how trusted knowers are visible through performance events, whether this is at a conference or debating in online forums. Particular people have been able to take a lead role in promoting preferred approaches to leaders, leading and leadership (e.g. Barber, 1996; Hopkins, 2007), where a proliferation and growth in «edu-business» (Mahony et al., 2004, p. 277) supply knowledge workers who can operate at national and local levels, with ministers and with teachers in classrooms.

Such knowledge workers may do research but it is often based on a narrow instrumental remit where the funder determines what is to be known and what is worth knowing. Such knowledge workers may popularize rather than necessarily do primary research, they package, communicate and affirm what has become known as «best practice» because it "works». Influential knowledge workers impact through their financial and social status whereby they "corporatize» (Saltman, 2010, p. 79) leadership either through individual philanthropy or through major consultancy companies (see Ball, 2010). It is what Jill Blackmore, Pat Thomson and myself (see "Series foreword» in Gunter, 2014) have called the Transnational Leadership Package (TLP) which we define as: 
- «[...] a set of policy prescriptions based on the experiences of consultants working in contractual (and often informal) partnerships with governments $[\ldots]$;

- «[...] a series of meta-analyses and effectiveness studies [...]»;

- «[...] a cultural professional deficit where the identification of problems, agenda setting and strategizing is often perceived as rightly located outside of the schools, and where notions of professional agency are reduced to tactical localized delivery». (p. x)

The outcome of this is that:

«[...] the TLP provides a kind of (largely) Anglocentric policy IKEA flat-pack of policy 'levers' that will produce the actions and effects that count in national elections and international testing. While modern but cheap, it is worth 'buying into' largely because to be seen as different is risky». (p. xi)

So the issue for those interested in developing educational leadership within Latin countries in Europe is whether you and they literally buy into the TLP because not to do this risks engaging with approaches that suggest unmodern approaches. Think about the situation in England, where educational professionals in schools have to handle rapid and sometimes contradictory demands for change and evidence of improvement. Their jobs depend on this. A key question is: who do headteachers turn to for support for ideas and strategies? They are located in a context whereby knowledge is increasingly marketised, where higher education is one provider amongst a range of knowledge workers who are consultants undertaking private fee charging consultancy. Let me give you an example. The experiments in England have been shaped by and contributed to the TLP have focused on functional knowledge production on the basis that educational problems can be solved by organizational and cultural changes. Hence one government commissioned project produced a summary text: Seven strong claims about successful school leadership (Leithwood et al., 2006), where such claims can be easily put onto electronic presentation slides, communicated and accepted in ways that are inspirational. In addition the evidence can be selected and controlled, where number one of these «strong claims» says «school leadership is second only to classroom teaching as an influence on pupil learning» (p. 3) but the recognition that teachers matter more than headteachers has not shifted the focus from headteachers to teachers and classroom processes. This functional knowledge is about removing dysfunctions, and can be descriptive with anecdotes and rousing metaphors, and can be normative whereby a lack of evidence does not prevent the promotion of leadership strategies that should be done, where the rhetoric advises that to do otherwise is equivalent to letting children down (see Gunter et al., 2013). While headteachers may profession- 
ally know that it is teachers who need to be invested in, they are required to focus on themselves through the external invocation of learning outcomes as the means through which entrepreneurship is accepted.

In England, the language of functional privatizing leaders, leading and leadership has come to dominate, and even replace professional and traditional titles such as headteacher, deputy headteacher, head of subject, pastoral head of year, and teacher. It seems that all are and should be leaders. However, in Europe there are countries where leader, leading and leadership do not have equivalent words, and so there are questions to be raised about colonization by the Anglophone world as new marketised professional products are developed and sold to your governments and professionals. This prompts me to argue that there is a need to think differently about educational leaders, leading and leadership.

\section{THINKING DIFFERENTLY ABOUT EDUCATIONAL LEADERSHIP}

Much is claimed about the impact of the financial and symbolic investment in leaders, leading and leadership within and of schools. UK politicians have made it clear that they believe in leadership, and that it is common sense to focus on the key person in an organization. As one former Secretary of State said: "I don't think we made a decision that we'd concentrate on leadership, there was not a point when that decision was made, it was obvious» (Gunter, 2012, p. 19). In addition, projects have been commissioned to demonstrate a correlational link between leadership and improvement (e.g. Day et al., 2009), and this general good news story has been enabled by heads who have published narratives about how they have turned schools around (e.g. Stubbs, 2003), how they are making reforms work (e.g. Astle \& Ryan, 2008), and how it is the best job in the world (e.g. Goddard, 2014). This message has crossed boundaries from one government to another, where the Conservative led Coalition government (2010-2015) also made claims about the importance of system leadership, an approach developed by Hopkins under the New Labour government (see Hopkins, 2007). The then Secretary of State, Michael Gove (2012) stated: «[...] the legacy of this success is widespread support for system leadership as the best method of school improvement [...]» (unpaged). The endurance and common sense notion of leadership means that there is an ongoing depoliticisation of education, where the solution to the big issues has been identified and sorted, and so all that has to be done is to collect data about effective implementation. 
There are two main things to say in response to this seemingly positive and exciting situation: first, that the endorsement of school leaders needs to be off-set against enduring challenges and concerns; and second, that the evidence base being drawn upon is narrow and fails to connect with more professional and educational models. Therefore as policymakers, professionals and researchers within Latin Europe consider leaders, leading and leadership as a reform strategy, there is a need to ask serious questions about what is being imported and what impact it may have on cultures and practices that you may wish to retain and strengthen.

In developing these ideas further I would like to begin by stating that the reform programme in England has been undertaken by people who actively believe in the changes and the need to improve teaching and learning. No one doubts that the system needed review and development, but it is the case that the privatization agenda as the elite neoliberal and neoconservative solution has been and continues to be challenged and resisted. This is taking place at a number of levels, whereby investigative journalists are revealing the way reforms are acting in the interests of powerful and wealthy groups (e.g. Beckett, 2007); researchers are opening up evidence about reforms that challenge the claims being made (e.g. Gunter, 2011); and professionals and researchers are outlining the impact on practice and learning in ways that challenge values (e.g. Arrowsmith, 2001; Thomson, 2009). Within civil society there are campaigns against the reforms, for example, the Anti-Academies Alliance that co-ordinates local resistance to enforced changes (Gunter, 2011). These attempts to keep politics vibrant and engaged with education are revealing significant contradictions within policy. For example, there is an espoused commitment to parental choice but successful schools are being forced to take up academy status against parental wishes; there are assurances that public education for all is safe but there is knowledge work and discourses around vouchers and for profit education; and, while there is a focus on children being enabled to learn, there are emerging allegiances to eugenics with questions about whether all children can benefit from public investment in education (see Gunter, 2014). I raise this because in thinking about something as seemingly normal and productive as a "good" leader for each school there is the possibility of what Bourdieu (2000) calls misrecognition. What I mean here is that in pursuing changes that make sense, and are framed as benefitting children (and may prevent harm by professional interpretations and local adaptations), there could be a failure to think about the implications of how those who think and do differently are treated and potentially excluded. Bourdieu asks us to think about what it means to be a «fish in water» because it may be that in our busy working lives we may not think about «the weight of the water» and like a fish we 
may «take the world about itself for granted» (Bourdieu \& Wacquant, 1992, p. 27). There are at least two ways in which to think about and challenge the reform waters in which we are all swimming (and some drowning in): first, a research approach, and second, a political approach.

In taking the research issue first, I would want to make the case that the field of leadership studies within, for and about education is pluralistic. By this I mean that there are a range of knowledge claims that the field has a resource. Much of what I have already outlined as being used to support and being developed by policymakers is functional knowledge production. Here the focus is on technical improvements that treat the school as unitary organization whereby the language is one of «levers» for change. In my work on distributed leadership there is evidence of how this has led to concerns about heroic forms of transformation, and so work has been done on how leadership takes place outside of the headteachers office. However, it is also clear that this research does not challenge the structures and cultures in place, but is about making hierarchy work in more humane and seemingly professional ways. Where such evidence about distributed leadership is not available, the profession is exhorted to take on this approach as good practice (see Gunter et al., 2013). What our work at Manchester shows is that the functional literatures (e.g. Leithwood et al., 2006) draw boundaries around the knowledge that is considered to be legitimate in thinking about school leadership. Importantly there are some references to critical literatures but socially critical work is a place where this community does not seem to travel to. Travelling here suggests purposes that are about public education staffed by trained and accredited professionals, with rationales about expertise and inclusion, and narratives about equity based on professional skills and care.

Critical approaches are therefore concerned with the realities of doing the job, not least the risky nature of performance management where the professional disposition to include colleagues in strategy may be problematic given the high stakes involved in league tables and competition (see Gunter et al., 2013). Nevertheless there is evidence that headteachers do not automatically accept the elite leadership agenda or the privatization of school provision, where some are actively working for public education (see Gunter \& Forrester, 2009). The emphasis on the doing of the job enables visibility for relational activity in schools, where what takes place may not be causally linked to the headteacher's charisma or vision. Indeed, this approach enables questions to be asked about why policymakers do not begin with enabling teachers to work together as knowledgeable experts on teaching and learning. This is particularly the case when victory stories by headteachers about how they have turned around a failing school may not be sustained, not least because the changes are not embedded in professional values and knowledge production. 
While this critical research remains a valuable resource, there are questions to be raised about how power is engaged with. This tends to be located in more socially critical work, whereby power structures that impact on schools regarding how advantage and disadvantage work are surfaced and challenge in regard to matters of social justice. Hence socially critical distributed leadership is concerned to challenge normalized hierarchy, and draws on examples of schools that have done this (Apple \& Beane, 1999; Hatcher, 2005), and ways of thinking about leadership that are inclusive of the profession and children's voice (Lingard et al., 2003; Wrigley et al., 2012).

The political approach is the second way to think about what it means to be a fish in water. The account I have just given of a range of thinking and knowledge within the field is one that would lead me to be decried by some individuals and groups within England. The quality of debate has seriously declined to the extent that people are concerned about a democratic deficit, not least how discourses operate mainly at the level of spin and denunciation. An illustrative example is how 200 professors of education signed a letter to a national newspaper to outline their concerns about curriculum reforms. I was one of the signatories. Following this the then Secretary of State for Education, Michael Gove, wrote a reply where he claimed that educational researchers are the "new Enemies of Promise» who are «a set of politically motivated individuals who have been actively trying to prevent millions of our poorest children getting the education they need» (Gove, 2013, unpaged). He goes on to identify researchers as Marxists, and uses that to claim that Universities are not safe places to train teachers. Importantly, this is not only about marginalizing and ridiculing researchers as independent experts, but also about refueling fear within the system about what can and cannot be said, and how jobs may be threatened through seeking to debate rather than deliver. Using Arendt's (1958) approach to politics I have been able to think about this as a current example of deliberate shifts within knowledge production towards labour and work. What I mean by this is that all aspects of education in England have been designed and scripted to teacher-proof teaching and learning. Hence discretion and judgement are minimized in favour of delivering lessons designed elsewhere, gathering data about performance, and putting in place technical change to improve the fidelity of delivery and the level of achievement. In Arendtian terms there is an emphasis on labour or doing what is necessity to survive, and there is some emphasis on work or crafting innovative approaches to labour. What is missing are forms of action where plurality is evident in regard to thinking and debate, where those who want to think differently are taken seriously rather than treated as "the enemy». In addition to this, Arendt argues for natality within action, where she claims that what is integral to action is the capacity to do something new. So in 
discussions regarding leaders, leading and leadership there is an imperative to begin on the basis that those in professional roles can do things differently and in ways that enable education to be productive and socially just. This is not through performance events with celebrity leaders, but through working for change with a culture of responsibility. Arendt enables those interested in professional identity and organizational matters to give recognition to how criticality is not the same as opposition. What such criticality does is to raise questions about how schools as organisations are more than technical units of production but are sites of relational activity, and that professionals are not just middle managers who deliver but have a range of resources that they can draw on to develop approaches to professional identity and activity. In regard to the European context there is also recognition of how the experience in England may be a resource to draw upon and even borrow from, but there should also be a critical approach so that the wider context is taken into account. What seems to be a rational and modernizing process is actually a strongly ideological process of privatization, it is deeply conservative, and where reforms in England are not necessarily transferrable. Indeed, research shows that the nation state in Europe continues to be a strong feature in how globalized reform solutions such as the TLP are engaged with, refused, adapted, and developed over time and within particular traditions (see Gunter \& Fitzgerald, 2013a and 2013b).

\section{ACKNOWLEDGEMENTS}

The ideas within this paper are based on three funded research projects: (1) ESRC (RES-000-23-1192), Knowledge production in educational leadership (£ 99,000); (2) ESRC (RES-000-22-3610), Distributed leadership and the social practices of school organisation in England (£ 96,361); (3) British Academy (SG121698), Consultancy and knowledge production in education project. This research has been undertaken with teams through the "Critical education policy and leadership thematic programme of research» at the University of Manchester, UK, and I am grateful to those who have given their support: Prof. David Hall, Colin Mills and Dr. Ruth McGinity and to all those «anonymised» professionals who have participated in the projects. 


\section{REFERENCES}

Apple, M. W., \& Beane, J. A. (1999). Democratic schools. Buckingham: Open University Press.

Arendt, H. (1958). The human condition (2nd ed.). Chicago: The University of Chicago Press.

Arrowsmith, R. (2001). A right performance. In D. Gleeson \& C. Husbands (Eds.), The performing school (pp. 33-43). London: RoutledgeFalmer.

Astle, J., \& Ryan, C. (Eds.). (2008). Academies and the future of state education. London: CentreForum.

Ball, S. J. (2007). Education PLC. London: Routledge.

Ball, S. J. (2010). New voices, new knowledges and the new politics of education research: The gathering of the perfect storm? European Educational Research Journal, 9(2), 124-137.

Barber, M. (1996). The learning game, arguments for a learning revolution. London: Victor Gollancz.

Beckett, F. (2007). The Great City Academy Fraud. London: Continuum.

Blackmore, J., Gunter, H. M., \& Thomson, P. (2014). Series foreword. In H. M. Gunter, Educational leadership and Hannah Arendt. Abingdon: Routledge.

Bourdieu, P., \& Wacquant, L. J. D. (1992). An invitation to reflexive sociology. Cambridge: Polity.

Butt, G., \& Gunter, H. M. (Eds.). (2007). Modernizing schools: People, learning and organizations. London: Continuum.

Day, C., Sammons, P., Hopkins, D., Harris, A., Leithwood, K., Gu, Q., Brown, E., Ahtaridou, E., \& Kington, A. (2009). The impact of school leadership on pupil outcomes. London: Department for Children, Schools and Families - National College for School Leadership.

Foster, W. (1986). Paradigms and promises. Amherst, NY: Prometheus Books.

Goddard, V. (2014). The best job in the world. Bancyfelin: Independent Thinking Press.

Gove, M. (2012). Michael Gove at the National College Annual Conference. https:// www.gov.uk/government/speeches/michael-gove-at-the-national-collegeannual-conference (accessed 02/06/2014).

Gove, M. (2013). I refuse to surrender to the Marxist teachers hell-bent on destroying our schools: Education Secretary berates «the new enemies of promise» for opposing his plans. Mailonline. http://www.dailymail.co.uk/debate/ article-2298146/I-refuse-surrender-Marxist-teachers-hell-bent-destroyingschools-Education-Secretary-berates-new-enemies-promise-opposing-plans. html (accessed 09/06/2014).

Grace, G. (1995). School leadership: Beyond educational management. London: Falmer. 
Gunter, H. M. (Ed.). (2011). The state and education policy: The academies programme. London: Continuum.

Gunter, H. M. (2012). Leadership and the reform of education. Bristol: Policy.

Gunter, H. M. (2014). Educational leadership and Hannah Arendt. Abingdon: Routledge.

Gunter, H. M. (2015). An intellectual history of school leadership practice and research. London: Bloomsbury.

Gunter, H. M., \& Fitzgerald, T. (2013a). New Public Management and the modernisation of education systems 1. Journal of Educational Administration and History, 45(3), 213-282.

Gunter, H. M., \& Fitzgerald, T. (2013b). New Public Management and the modernisation of education systems 2. Journal of Educational Administration and History, 45(4), 303-394.

Gunter, H. M., \& Forrester, G. (2009). Education reform and school leadership. In S. Brookes \& K. Grint (Eds.), The public sector leadership challenge (pp. 54-69). London: Palgrave.

Gunter, H. M., Hall, D., \& Bragg, J. (2013). Distributed leadership: A study in knowledge production. Educational Leadership, Management and Administration, 41(5), 556-581.

Gunter, H. M., Hall, D., \& Mills, C. (Eds.). (2014). Education policy research: Design and practice at a time of rapid reform. London: Bloomsbury.

Gunter, H. M., \& Thomson, P. (2009). The makeover: A new logic in leadership development in England? Educational Review, 61(4), 469-483.

Gunter, H. M., \& Thomson, P. (2010). Life on Mars: Headteachers before the National College. Journal of Educational Administration and History, 42(3), 203-222.

Hall, D., Gunter, H. M., \& Bragg, J. (2012). Leadership, New Public Management and the re-modeling and regulation of teacher identities. International Journal of Leadership in Education, 16(2), 173-190.

Hatcher, R. (2005). The distribution of leadership and power in schools. British Journal of Sociology of Education, 26(2), 253-267.

Hopkins, D. (2007). Every school a great school. Maidenhead: Open University Press.

Leithwood, K., Day, C., Sammons, P., Harris, A., \& Hopkins, D. (2006). Seven strong claims about successful school leadership. Nottingham: NCSL.

Lingard, B., Hayes, D., Mills, M., \& Christie, P. (2003). Leading learning. Maidenhead: Open University Press.

Mahony, P., Hextall, I., \& Menter, I. (2004). Building dams in Jordan, assessing teachers in England: A case study in edu-business. Globalisation, Societies and Education, 2(2), 277-296. 
National College for Leadership of Schools and Children's Services (2010). Successful leadership in times of change. Nottingham: National College for Leadership of Schools and Children's Services.

OECD (2001). Public sector leadership for the 21st century. Paris: OECD.

Pont, B., Nusche, D., \& Moorman, H. (2008). Improving school leadership, Vol. 1: Policy and practice. Paris: OECD.

Pont, B., Nusche, D., \& Hopkins, D. (2008). Improving school leadership, Vol. 2: Case studies on system leadership. Paris: OECD.

Saltman, K. J. (2010). The gift of education. New York: Palgrave Macmillan.

Stubbs, M. (2003). A head of the class. London: John Murray.

Thomson, P. (2009). School leadership, heads on the block? London: Routledge.

Wrigley, T., Thomson, P., \& Lingard, B. (Eds.). (2012). Changing schools, alternative ways to make a world of difference. Abingdon: Routledge.

\section{Riassunto}

La rapida crescita, nei paesi anglofoni, del numero di dirigenti che esercitano la leadership, ha generato, in coloro che non appartengono allo stesso contesto, il desiderio di indagarne le caratteristiche con lo scopo di sviluppare una propria organizzazione originale nello stesso ambito. In questo articolo esamino le sperimentazioni condotte in Inghilterra da parte dei diversi governi britannici che si sono susseguiti, e attingo ai dati di ricerca, forniti da una serie di progetti, per descrivere e per esaminare criticamente il programma attuato. Avanzo seri interrogativi rivolti a responsabili politici, professionisti e ricercatori che sono interessati alla leadership educativa in Europa Latina; in particolare rilevo che le finalità, le motivazioni e i resoconti in Inghilterra sono meno legati alla dimensione educativa della leadership e più centrati sui vantaggi e sui risultati che da essa derivano. Mostro come ciò sia legato all'ampia privatizzazione che si sta attuando in Inghilterra, e fornisco alcune prove di come sia possibile individuare approcci alternativi da applicare nella pratica educativa e nella ricerca ad essa correlata. Perciò l'Europa Latina ha a sua disposizione una vasta gamma di risorse alle quali attingere e che potrebbe utilizzare a sostegno della teoria e delle strategie applicative che afferiscono al tema della leadership.

Parole chiave: Leadership, Leadership educativa, Politica dell'istruzione, Riforma della leadership in Inghilterra, Riforma dell'istruzione. 